\title{
EVALUASI PENGELOLAAN SAMPAH MEDIS DI RUMAH SAKIT MUHAMMADIYAH TUBAN TAHUN 2018
}

Herlina Widyastuti, Demes Nurmayanti, S.B Eko Warno

\begin{abstract}
ABSTRAK
Limbah di rumah sakit salah satunya menghasilkan sampah medis yang harus dikelola dengan benar agar tidak mencemari lingkungan. Pengelolaan sampah medis di Rumah Sakit Muhammadiyah Tuban, masih ditemukan percampuran sampah medis di tempat sampah non medis, tahap pengangkutan tempat sampah tidak dapat tertutup rapat, pengangkutan menggunakan lift umum dan penyimpanan sampah medis lebih dari 24 jam sehingga terjadi penimbunan sampah medis di TPS B3. Tujuan penelitian ini adalah mengetahui sistem pengelolaan sampah medis di Rumah Sakit Muhammadiyah Tuban.

Jenis penelitian deskriptif yaitu menggambarkan keadaan secara obyektif. Variabel yang diteliti meliputi timbulan sampah, pemilahan, pengumpulan, pengangkutan, penyimpanan sementara, SDM, kebijakan rumah sakit dan sarana prasarana. Teknik pengumpulan data dilakukan dengan cara wawancara, observasi dan pengukuran volume sampah medis selama 7 hari. Penampilan data dalam bentuk tabel dan dianalisis menggunakan analisis SWOT.

Hasil penelitian, RS Muhammadiyah Tuban menghasilkan timbulan sampah medis rata-rata $18,15 \mathrm{~kg} /$ hari. Penilaian pengelolaan sampah medis pada pemilahan $83 \%$, pengumpulan $88,8 \%$ sudah memenuhi syarat tahap pengangkutan dan penyimpanan sementara tidak memenuhi syarat dengan prosentase $66,7 \%$ dan $70 \%$. Pelaksanaan pengelolaan sampah medis sesuai dengan SOP yang ditetapkan direktur, SDM yang mengelola berpengetahuan baik dan sarana prasarana yang mencukupi sesuai jumlah sampah yang dihasilkan. Hasil analisis SWOT didapatkan strategi untuk memperbaiki pengelolaan sampah medis kan dengan memanfaatkan kekuatan dan peluang yang ada diantaranya, melakukan pelatihan untuk meningkatkan kualitas SDM, melaksanakan tugas sesuai dengan struktur organisasi yang ada dan menyusun prosedur tetap sesuai peraturan yang berlaku.

Sistem pengelolaan sampah medis di RS Muhammadiyah Tuban secara umum sudah baik, tetapi masih ada beberapa tahap yang belum sesuai sehingga perlu Perlu monitoring pelaksanaan pengelolaan sampah medis sesuai SOP dan perlu adanya pelatihan pada petugas pengelola sampah medis untuk meningkatkan kualitas pengelolaan sampah medis.

Kata Kunci : Pengelolaan sampah medis, Sampah medis, SWOT

\section{PENDAHULUAN}

Pembangunan

kesehatan

pada

dasarnya bertujuan untuk meningkatkan derajat kesehatan masyarakat. Salah satu pelayanan kesehatan yang berperan penting dalam upaya peningkatan

kesehatan yaitu rumah sakit. Persyaratan kesehatan lingkungan rumah sakit diatur dalam Kepmenkes RI No. 1204/Menkes/SK/X/2004 yang bertujuan untuk mencegah dan mengurangi risiko dengan pengendalian
\end{abstract}


terhadap bahaya yang dapat terjadi pada petugas, pasien dan masyarakat sekitar terutama bahaya infeksi nosokomial. Salah satu bahaya yang dapat menimbulkan risiko adalah limbah medis cair, padat, dan gas.

Pelaksanaan kegiatan pelayanan kesehatan, rumah sakit menghasilkan sejumlah sampah medis yang dapat membahayakan kesehatan masyarakat terutama sampah medis yang terkontaminasi virus maupun kuman. Sampah medis yang dihasilkan oleh rumah sakit, khususnya sampah infeksius belum dikelola dengan baik, masih ada pencampuran sampah medis dan non medis dan pengelolaannya masih disamakan antara sampah medis infeksius dan non infeksius (Asmadi, 2013). Pengelolaan sampah medis rumah sakit yang baik dan benar sangat dibutuhkan untuk memperoleh kenyamanan dan kebersihan lingkungan rumah sakit sehingga dapat mencegah timbulnya masalah kesehatan. Prosedur tetap yang digunakan sebagai acuan untuk pengelolaan sampah medis rumah sakit sangat berpengaruh pada keberhasilan sistem pengelolan sampah medis. (Line dan Lilis, 2013).
Berdasarkan survei pendahuluan pada pengelolaan sampah medis di Rumah Sakit Muhammadiyah Tuban, masih ditemukan sampah medis pada tempat sampah non medis, tempat sampah pengangkut tidak dapat tertutup rapat, rute pengangkutan masih menggunakan lift umum, waktu penyimpanan sampah medis di TPS B3 selama 1 minggu, terjadi penimbunan sampah di TPS B3 dan pengambilan sampah medis oleh pihak ketiga tidak dilakukan secara keseluruhan.

\section{METODE PENELITIAN}

Penelitian ini adalah deskriptif dengan tujuan utama menggambarkan tentang pengelolaan sampah medis di Rumah Sakit Muhammadiyah Tuban Tahun 2018. Variabel penelitian ini terdiri dari timbulan sampah medis, pemilahan, pengumpulan, pengangkutan, penyimpanan sementara, kebijakan rumah sakit, sumber daya manusia serta sarana dan prasarana. Pengumpulan data dengan wawancara, observasi dan pengukuran jumlah sampah. Data ditampilkan dengan tabel dan dianalisis menggunakan SWOT. 


\section{HASIL PENELITIAN DAN PEMBAHASAN}

A. Timbulan Sampah Medis

Tabel 1

TIMBULAN SAMPAH MEDIS PER HARI DI RUMAH SAKIT MUHAMMADIYAH TUBANTAHUN 2018

\begin{tabular}{|c|c|c|c|c|c|c|c|c|}
\hline \multirow{2}{*}{ Ruangan } & \multicolumn{7}{|c|}{ Hasil timbulan sampah per hari (kg) } & \multirow{2}{*}{$\begin{array}{l}\text { Total } \\
(\mathbf{k g})\end{array}$} \\
\hline & 1 & 2 & 3 & 4 & 5 & 6 & 7 & \\
\hline Sofa & 2,5 & 2 & 1,5 & 3 & 3 & 3,5 & 2 & 17,5 \\
\hline Marwah & 3 & 2 & 2 & 3,5 & 2 & 4 & 2 & 18,5 \\
\hline $\mathrm{HCU}$ & 2 & 1,5 & 2 & 2 & 1,5 & 2,5 & 1 & 12,5 \\
\hline Isolasi & 1,5 & 1 & 1 & 2 & 1,5 & 2,5 & 1 & 10,5 \\
\hline Observasi & 1 & 2 & 1 & 1,5 & 2 & 2,5 & 1 & 11 \\
\hline Mina & 3 & 4 & 2 & 4 & 3,5 & 5 & 3 & 27,5 \\
\hline Neonatus & 2,5 & 2,5 & 1,5 & 2 & 2,5 & 3 & 2 & 16 \\
\hline Oka & 2,5 & 2 & 1 & 2,5 & 2,5 & 3 & 2 & 15,5 \\
\hline $\begin{array}{l}\text { Jumlah per } \\
\text { hari (kg) }\end{array}$ & 18 & 17 & 13 & 20,5 & 18,5 & 26 & 14 & 127 \\
\hline
\end{tabular}

Tabel 1 merupakan hasil pengukuran timbulan sampah medis selama 7 hari yang dihasilkan di RS Muhammadiyah Tuban. Jumlah ratarata sampah medis yang dihasilkan tidak melebihi hasil yang ditetapkan oleh WHO dalam Pedoman Kriteria Teknologi Pengelolaan Limbah Medis Ramah Lingkungan (2014) yaitu sebesar $30 \mathrm{~kg} / \mathrm{hari}$. Penelitian ini sejalan dengan penelitian Amien (2015) bahwa timbulan sampah yang dihasilkan tidak melebihi yang ditetapkan maka tidak terjadi penumpukan di ruangan karena sudah dilakukan pengangkutan setiap hari.

Rata-rata timbulan sampah tersebut, dapat berpotensi terjadinya penimbunan di TPS B3 jika penyimpanan terlalu lama dan akan berdampak pada pencemaran lingkungan. Hal ini merupakan ancaman bagi RS Muhammadiyah Tuban jika tidak dilakukan pengelolaan dengan baik. Menurut penelitian Yunizar (2014), timbulan sampah medis dapat berpotensi terjadinya penimbunan jika pemusnahan dilakukan lebih dari 2 hari. Dampak yang dapat ditimbulkan yaitu menjadi sumber kontaminasi karena vektor akan lebih cepat berkembang biak sehingga perlu dilakukan penanganan sesuai dengan waktu yang telah ditetapkan. 
B. Proses pengelolaan sampah medis

Tabel 2

HASIL PENILAIAN PROSES PENGELOLAAN SAMPAH MEDIS

DI RUMAH SAKIT MUHAMMADIYAH TUBAN TAHUN 2018

\begin{tabular}{|c|c|c|c|c|}
\hline No & Variabel & $\begin{array}{l}\text { Jumlah } \\
\text { skor }\end{array}$ & $\begin{array}{c}\text { Total } \\
\text { skor yang } \\
\text { diperoleh }\end{array}$ & $\begin{array}{c}\text { Prosentase } \\
\text { Skor }(\%)\end{array}$ \\
\hline 1 & Pemilahan & 6 & 5 & 83,3 \\
\hline 2 & Pengumpulan & 9 & 8 & 88,8 \\
\hline 3 & Pengangkutan & 8 & 6 & 66,7 \\
\hline 4 & $\begin{array}{l}\text { Tempat } \\
\text { sementara }\end{array}$ & 10 & 7 & 70 \\
\hline & Jumlah & 34 & 26 & 76,5 \\
\hline
\end{tabular}

1. Pemilahan

medis.Pengambilan sampah medis

Pemilahan sampah di RS Muhammadiyah Tuban sudah memenuhi syarat. Pada setiap unit tersedia tempat sampah yang terpisah untuk sampah medis dan non medis. Tempat sampah yang tersedia dilengkapi dengan penutup dan terbuat dari bahan yang kuat, kedap air, mudah dibersihkan, mudah dikosongkan, dilapisi dengan kantong plastik sesuai jenisnya. Sampah jenis jarum atau benda tajam ditempatkan pada safety box yang disediakan disetiap ruangan. Hal ini sesuai dengan persyaratan Djohan, AJ dan Devy Halim (2013) tentang persyaratan tempat sampah medis.

2. Pengumpulan

Pengumpulan sampah medis di RS Muhammadiyah Tuban sudah memenuhi syarat. Pada proses pengumpulan sampah medis, dikumpulkan menjadi satu di titik pengumpulan untuk diangkut petugas pengelola sampah

kali sehari, tetapi jika tempat sampah sudah terisi $2 / 3$ bagian tidak segera diambil sehingga dapat beresiko menjadi tempat perindukan vektor. Hal ini tidak sesuai dengan Kepmenkes No. 1204/Menkes/SK/X tahun 2004 tentang Kesehatan Lingkungan Rumah Sakit. Menurut penelitian Misgiono (2014), upaya yang harus dilakukan agar pelaksanaan tahap pengumpulan sesuai dengan ketentuan yaitu dengan adanya koordinasi antar instalasi dalam rangka pengelolaan sampah medis berdasarkan kebijakan yang sesuai serta sosialisasi tentang adanya SOP yang telah ditetapkan.

3. Pengangkutan

Pengangkutan sampah medis di RS Muhammadiyah Tuban tidak memenuhi syarat. Pengangkutan sampah medis tidak menggunakan 
troli khusus. Pengangkutan ini dilakukan sesuai jadwal sehingga jika volume sampah sudah terisi $2 / 3$ bagian, tidak segera dilakukan pengambilan. Rute pengangkutan sampah medis masih menggunakan lift untuk pasien atau pengunjung maupun makanan tetapi petugas pengelola sampah tetap dihimbau harus berhati-hati dalam mengangkut sampah medis agar tidak tercecer selama pengangkutan.

4. Tempat Penyimpanan Sementara Sampah Medis

TPS medis di RS Muhammadiyah Tuban tidak memenuhi syarat karena tempat penyimpanan tidak berupa bak permanen, waktu penyimpanan lebih dari 2 hari sehingga tidak sesuai dengan Kepmenkes No. 1204 Tahun 2004. Menurut Muftah dan Atik (2011) bahwa penyimpanan dilakukan 2 sampai 3 hari karena kebutuhan untuk penyesuaian dengan jadwal pembakaran yang dilakukan oleh pihak ketiga, selain itu ada rumah sakit yang tidak memiliki insinerator.

C. Identifikasi faktor yang berpengaruh dalam pengelolaan sampah medis

1. Kebijakan Rumah Sakit

Kebijakan yang digunakan Rumah Sakit Muhammadiyah Tuban sebagai pedoman pelaksanaan pengelolaan sampah medis berdasarkan Kepmenkes No. 1204 Tahun 2004 kemudian digunakan menyusun SOP yang ditetapkan direktur pada tahun 2015. Berdasarkan analisis SWOT terkait faktor internal dan eksternal pengelolaan sampah medis, terdapat SOP untuk pengelolaan sampah medis merupakan kekuatan yang ada di dalam Rumah Sakit Muhammadiyah Tuban serta terdapat peluang yaitu adanya Kepmenkes RI No. 1204 Tahun 2004 yang digunakan sebagai pedoman pengelolaan sampah. Dengan adanya kekuatan dan peluang dapat memanfaatkan keduanya untuk memperbaiki pengelolaan sampah medis dengan cara menyusun prosedur tetap sesuai dengan peraturan yang berlaku.

2. Sumber Daya Manusia

Tenaga pengelola sampah medis di Rumah Sakit Muhammadiyah Tuban hanya 2 orang dengan kualifikasi pendidikan lulusan SD dan SMP dan belum pernah mengikuti pelatihan. Dalam melaksanakan pengelolaan sampah medis berdasarkan rutinitas saja, namun tetap sesuai dengan pedoman yang ditetapkan oleh rumah sakit. Koordinator

yang bertanggungjawab bergabung dengan bagian pemeliharaan dengan kualifikasi pendidikan SMA. Hasil analisis SWOT pada faktor internal dan eksternal terkait SDM dapat diketahui bahwa di Rumah Sakit Muhammadiyah terdapat kekuatan, kelemahan serta peluang yang dapat mempengaruhi pengelolaan sampah medis. Setelah diketahui faktor kekuatan, kelemahan dan peluang dalam pengelolaan 
sampah medis dapat memanfaatkan kekuatan dan peluang untuk meminimalkan kelemahan yang dapat terjadi. $\mathrm{Hal}$ tersebut dapat dilakukan dengan cara pembagian tugas sesuai struktur organisasi instalasi, meningkatkan kualitas SDM dengan pelatihan pengelolaan sampah medis, menambah SDM sebagai penanggungjawab instalasi sanitasi sehingga dapat meningkatkan kualitas pengelolaan sampah medis di rumah sakit.

3. Sarana dan prasarana

Sarana dan prasarana untuk pengelolaan sampah medis di RS Muhammadiyah Tuban cukup memadai. Tersedia tempat sampah medis dan non medis di setiap unit. Tempat sampah untuk sampah kimia dan farmasi tidak disediakan, sampah kimia yang dihasilkan berupa cairan sehingga dikumpulkan pada jurigen terlebih dulu sebelum dibuang. Tersedia safety box untuk sampah benda tajam. Hasil analisis SWOT adanya sarana prasarana yang mencukupi merupakan suatu kekuatan yang mendukung pada pengelolaan sampah medis dan melakukan kerjasama dengan pihak ketiga dalam pemusnahan sampah medis. Kedua hal tersebut menjadi kekuatan dan peluang yang dapat dimanfaatkan oleh rumah sakit dalam memperbaiki pengelolaan sampah medis.
D. Evaluasi Pengelolaan Sampah Medis dengan Analisis SWOT

Identifikasi masalah dalam pengelolaan sampah medis dapat diketahui faktor internal (kekuatan dan kelemahan) serta faktor eksternal (peluang dan ancaman) dalam pengelolaan sampah medis. Faktor internal (kekuatan) yang ada di rumah sakit mendukung pelaksanaan pengelolaan sampah medis yaitu adanya sumber daya manusia, adanya SOP sebagai pedoman pelaksanaan pengelolaan sampah medis. Pelaksanaan pengelolaan juga terdapat beberapa kelemahan diantaranya petugas pengelola sampah medis belum mengikuti pelatihan, penanggungjawab instalasi sanitasi belum ada, masih terjadi ketidaksesuaian dengan prosedur. Dalam pengelolaan sampah medis terdapat faktor eksternal yaitu peluang dan ancaman. Adapun peluang bagi rumah sakit diantaranya melakukan kerjasama dengan pihak ketiga terkait pemusnahan sampah medis dan adanya pelatihan pada petugas pengelola sampah. Adapun ancaman bagi rumah sakit yaitu penimbunan sampah yang terlalu lama dan terjadinya pencemaran lingkungan sekitar rumah sakit. Setelah diketahui faktor internal dan eksternal selanjutnya dilakukan analisis untuk mengetahui strategi memperbaiki sistem pengelolaan sampah. Adapun alternatif strategi pengelolaan sampah medis yang dapat digunakan 1) meningkatkan kualitas SDM dengan pelatihan khususnya dalam pengeolahan 
sampah medis, 2) menyusun prosedur tetap sesuai peraturan, 3) menambah SDM untuk penanggung jawab pengelolaan sampah medis, 4) meningkatkan pelaksanaan pengelolaan sampah medis sesuai peraturan, 5) meningkatkan kualitas petugas untuk mencegah terjadinya pencemaran lingkungan.

\section{Kesimpulan}

Jumlah sampah medis yang dihasilkan di Rumah Sakit Muhammadiyah Tuban rata-rata sebesar 18,15 kg/hari. Pemilahan dan pengumpulan di rumah sakit sudah memenuhi syarat sesuai SOP dengan prosentase $83,3 \%$ dan $88,8 \%$. Pengangkutan dan penampungan sementara tidak memenuhi syarat dengan prosentase $66,7 \%$ dan $70 \%$. Pengelolaan sampah medis dipengaruhi oleh faKtor, diantaranya pelaksanaan pengelolaan sampah medis yang telah ditetapkan oleh direktur rumah sakit pada tahun 2015, sumber daya manusia melakukan pengelolaan sesuai SOP. Hasil analisis SWOT menunjukkan kekuatan dan peluang besar untuk memperbaiki pengelolaan sampah medis dengan melakukan pelatihan untuk meningkatkan kualitas SDM, melaksanakan tugas sesuai struktur organisasi dan menyusun prosedur sesuai peraturan.

\section{Saran}

Perlu adanya perbaikan perjanjian dengan pihak ketiga dalam pengangkutan sampah medis untuk menghindari penumpukan di TPS dan perlu meningkatkan proses pengelolaan sampah medis sesuai SOP yang ditetapkan serta perlu adanya pelatihan pada petugas pengelola sampah medis untuk meningkatkan kualitas pengelolaan sampah medis.

\section{Daftar pustaka}

Asmadi, 2013. Pengelolaan Limbah Medis Rumah Sakit (Pertama). Yogyakarta: Gosyen Publishing. Djohan, A.J dan Devy Halim, 2013. Pengelolaan Limbah Rumah Sakit. Jakarta: Salemba Medika.

Keputusan Menteri Kesehatan Republik Indonesia Nomor 1204/Menkes/SK/X/2004 Tentang Persyaratan Kesehatan Lingkungan Rumah Sakit. Jakarta: Direktorat Penyehatan Lingkungan.

Line, Domy dan Lilis Sulistyorini, 2013. Evaluasi Sistem Pengelolaan Sampah di Rumah Sakit Umum Daerah Blambangan Banyuwangi, Jurnal Kesehatan Lingkungan. Departemen Kesehatan Lingkungan Fakultas Kesehatan Masyarakat Universitas Airlangga. Vol. 7, No. 1, Hal. 71-75. Misgiono, Onay Setiani dan Budiyono, 2014.

Evaluasi Manajemen Limbah Padat dan Cair di RSUD Mimika, Jurnal Kesehatan

Lingkungan Indonesia. Program Magister Kesehatan Lingkungan. Universitas Diponegoro. Vol. 13, Hal. 1. Yunizar, Ahmad dan Akhmad Fauzan, 2014. Sistem Pengelolaan Limbah Padat pada Rumah Sakit Dr. H. Moch. Ansari Saleh Banjarmasin, Artikel Penelitian. Fakultas Kesehatan Masyarakat. UNISKA. Vol. 1, no. 1, hal. 5-9. 